\title{
A Method for Determining the Optimum Flight Altitude of an Unmanned Aerial Vehicle for Aerial Photography Tasks
}

\section{Vasyl Myklukha ${ }^{1}$}

${ }^{1}$ Serhiy Korolyov Zhytomyr Military Institute

22 Prospect Myru, Zhytomyr, 10004, Ukraine

DOl: $10.22178 /$ pos.58-1

LCC Subject Category: TA1-2040

Received 23.04.2020

Accepted 28.05.2020

Published online 31.05.2020

Corresponding Author:

vas83mik@gmail.com

(C) 2020 The Author. This article

is licensed under a Creative Commons

Attribution 4.0 License @)

Abstract. The article is devoted to the topic of current scientific interest, namely determination of flight altitude of an unmanned aerial vehicle (UAV), depending on the type of the tasks and UAV performance characteristics.

The article analyzes the current state of development of unmanned aerial vehicles and the range of tasks that are assigned to them. There is a number of unresolved problems, which determine the altitude of the UAV flight, depending on the type of the tasks. It is analyzed which main UAV performance and payload characteristics affect the flight altitude.

The approaches for determining the altitude of UAV flight are considered and their advantages and disadvantages are analyzed. A method of determining the altitude of UAV flight is introduced, which takes into account the specificity of the tasks and the quality of aerial photography.

The main obtained results and directions of further research to determine the UAV flight altitude for solving the tasks are highlighted.

Keywords: unmanned aerial vehicle; flight altitude; multicriteria optimization; aerial photography; multiplicative convolution.

\section{INTRODUCTION}

At present, worldwide practice tends to expand the use of UAVs in various realms, for example, to solve the problems of environmental monitoring, remote sensing of the Earth's surface, observing the objects of transport infrastructure, etc. In this case, UAV movement can occur in a variety of complex terrain conditions: in urban environment (among buildings), in mountainous terrain conditions, over deserted, forested parks, aquatic environments, etc. With the rapid development of UAV capable to move under complex terrain conditions, the task of planning and determining flight characteristics of UAVs is becoming increasingly relevant [1].

Issues regarding the use of UAVs for aerial photography are discussed in reference [1]. References $[2,3]$ are devoted to the process of planning the application of UAVs. In [4, 5], the main indices that influence the quality of the obtained aerial photography results are analyzed, and reference [6] is aimed to determine the viewing area during the aerial photography. Still in these references the issue of the influence of the height on the quality of aerial photography using UAV has not been fully addressed.

In [7] the general concepts of the decisionmaking system are considered. References [8, 9, 10] are devoted to multicriteria problems and multicriteria optimization. These references consider in detail the conception of solving multicriteria problems, their advantages and disadvantages. The investigated approaches to minimizing vector performance indices are discussed in detail in [11].

Reference [12] is devoted to the methods of obtaining a generalized criterion. In this paper the multiplicative convolution has been analyzed in detail, as well as its advantages and disadvantages in comparison with other approaches.

All the same, the aforementioned papers did not pay enough attention to the aerial photography using UAVs. The issue of determining the UAV flight altitude considering the specifics of the tasks was not considered. Thus, it can be concluded that the issue of determining the UAV 
flight altitude to perform aerial photography tasks is relevant.

Suppose it is given a particular type of UAV with a specific payload. A UAV has the defined parameters for aerial photography: resolution $R$, probability of object recognition in the image $P_{\text {poз , and frame area }} S_{k}$.

It is necessary to determine optimal flight altitude of UAVs $H_{o p t}$, which will satisfy the following conditions:

$$
H_{o p t}\left(Y\left(R, P_{p 03}, S_{k}\right)\right) \Rightarrow\left\{\begin{array}{l}
R \rightarrow \min , \\
P_{p о з} \rightarrow \max , \\
S_{k} \rightarrow \max .
\end{array}\right.
$$

The aim of the article is to invent a method to determine the optimal flight altitude of UAVs to ensure that the tasks are performed with a probability of not less than the specified ones.

\section{RESULTS AND DISCUSSION}

The UAVs application for aerial photography and terrain monitoring tasks creates an ambiguous practical task for choosing the height to perform the tasks. After all, the UAV flight altitude is one of the flight characteristics, which depends on the quality of the tasks performance and the flight route.

Therefore, at the same time when a UAV is flying at a certain altitude $\mathrm{H}_{3}$ and with a known scan angle $\varphi$, several target objects $\left(\mathrm{O}_{1}, \mathrm{O}_{2}, \mathrm{O}_{3}, \mathrm{O}_{4}\right)$ can be identified in the viewing area, as shown in Figure 1.

To find the solutions for the problems of aerial photography using UAVs, let us define the main indices that will affect the quality of the assigned tasks. These indices are supposed to define the resolution, the probability of recognizing the objects in the image, and the coverage area of the photography zone (the square of the obtained frame).

The introduced method of determining the optimal UAVs flight altitude when performing aerial photography tasks is based on finding a compromise solution that will take into account all the indices and will provide the necessary probability of successful completion of the assigned tasks.

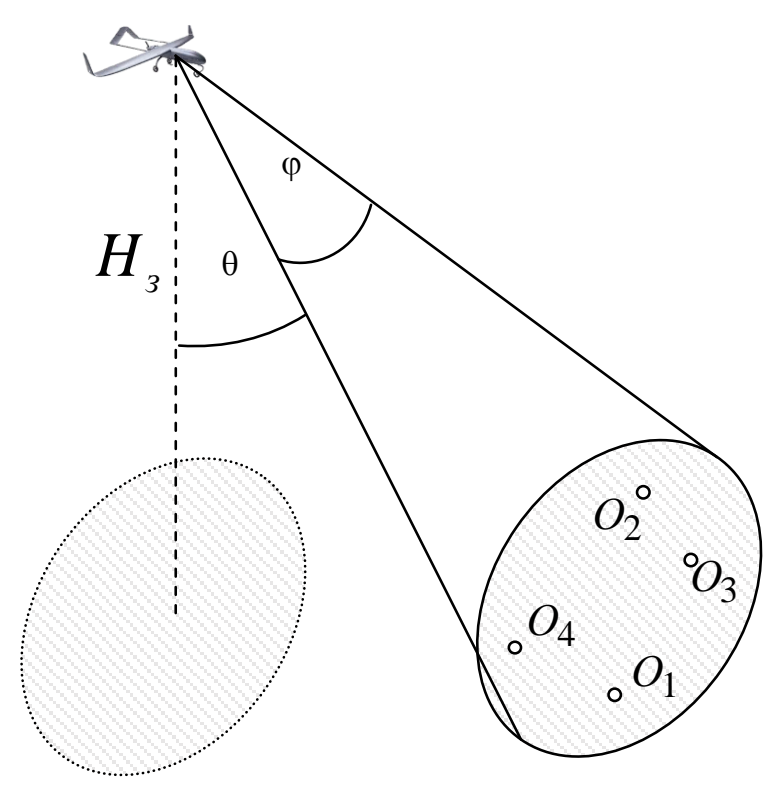

Figure 1 - Aerial photography by applying UAV

For step 1 of the method we need to calculate resolution of the image $R$ and contrast $K$ under the specified aerial photography conditions. The resolution depends on photography height $H_{3}$, focal length of the payload $f$, size of an elementary unit of the payload matrix $\omega$, deflection angle of the optical axis from the nadir $\theta$, and is calculated by expression [4]:

$$
R=\frac{\omega \cdot H_{3}}{f \cdot \cos \theta} .
$$

The image contrast is calculated as a relation of object background brightness $M_{o}$ and photography area background brightness by expression [4]:

$$
K=\frac{\left|M_{o}-M_{\phi}\right|}{M_{o}+M_{\phi}} .
$$

Step 2 assumes the calculation of probability of object recognition in the image $P_{\text {роз }}$, which depends on resolution of the payload $R$, a required resolution $R_{0}$ and contrast $K$, and is determined by expression [4]: 


$$
P_{\text {роз }}=\exp \left[\frac{\ln \alpha}{\log \left(\frac{1+K}{1-K}\right)} \cdot\left(\frac{R}{R_{0}}\right)^{2}\right]
$$

Then expressions (2-4) are used to calculate the photo height:

$$
H_{3}=\sqrt{\frac{\log \left(\frac{1+K}{1-K}\right)}{\ln \alpha} \cdot \ln \left(P_{\text {роз }}\right) \cdot\left(\frac{f \cdot R \cdot \cos \theta}{\omega}\right)} .
$$

After that we calculated the frame area, which depends on photography height $H_{3}$, scan angle $\varphi$, deflection angle of optical axis from the nadir $\theta$, and is determined by [5]:

$$
S_{k}=\left(\frac{2 \cdot H_{3} \cdot \operatorname{tg}(\varphi / 2)}{\cos \theta}\right)^{2}
$$

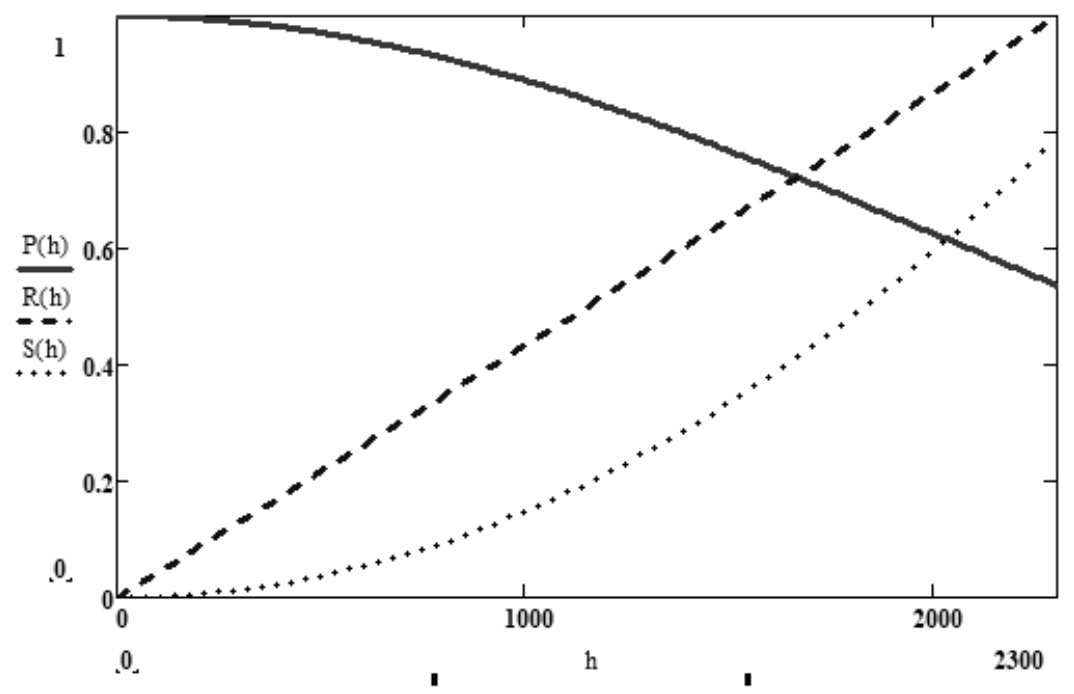

Figure 2 - The results of modeling of normalized indices

Modeling conditions:

1) the selected type of UAV is PD-1;

2) the payload is Sony Alpha 7R camera;

3) the contrast is $K=0,8$;
Step 3 of the introduced method is to select an optimization scheme using a decision-making theory, which includes the following steps:

1. Selecting a compromise scheme. The selection of the principle of optimality transforms the vector problem of making a decision to the scalar one. Multicriteria optimization methods allow us to effectively solve problems of different type [7]. The analyzing of the known methods $[8,10]$ and regarding the specificity of the tasks of aerial photography pointed to the superiority of a multiplicative convolution application under the given conditions as for there is a few partial criteria to be selected.

2. Defining priorities for partial criteria. Generally, partial criteria have different values when calculating a generalized criterion. This matters when selecting the optimal solution, giving preference to more important criteria.

The modeling of the dependence of normalized criteria on height (Figure 2) in the MathCAD software environment indicates the available optimal solution area (Pareto area). 
tage of defining the only optimal solution when we have a few partial criteria. Furthermore, when applying this type of convolution, there is no influence of different dimensions of the selected partial criteria. That is, there is no need to normalize the selected partial criteria, therefore there is no influence of the selected method of normalizing the criteria on the overall result [7, $11]$.

For step 4 we are to calculate a generalized criterion by the selected multiplicative convolution to find the priority coefficients of the partial criteria (in the course of calculations, there was taken the same priority of the partial criteria):

$$
\begin{gathered}
\lambda_{R}=\lambda_{P_{\text {роз }}}=\lambda_{S_{k}}, \quad \sum\left(\lambda_{R}, \lambda_{P_{\text {роз }}}, \lambda_{S_{k}}\right)=1, \\
Y\left(\lambda_{i}, \mu_{i}\right)=R^{\lambda R} \cdot P_{\text {роз }} \lambda_{P_{\text {роз }} \cdot S_{k}} \lambda_{S_{k}} .
\end{gathered}
$$

According to the developed mathematical model of the method, there was made a behavior modeling of a certain generalized criterion with increasing the height for two types of UAVs in the MathCAD software environment. Its results are shown in Figure 3.

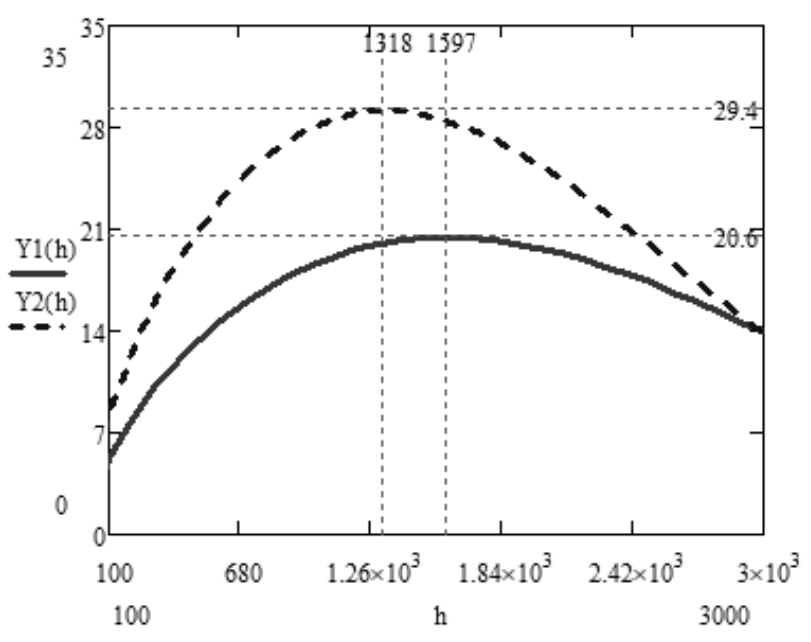

Figure 3 - The results of generalized criterion modeling for different types of UAV

Modeling conditions:

1) the selected types of UAVs are "PD-1" and "Stork-100";

2) the assigned task is to assure required resolution $R_{0}=0,15 \mathrm{M}$;
3) the contrast is $K=0,75$;

4) the deflection angle of the optical axis from the nadir is $\theta=10^{\circ}$;

5) the photography conditions are: day, clear weather.

The final step is to calculate the optimal height that will correspond to the maximum value of the generalized criterion:

$$
H_{o p t}=H\left(\max Y\left(R, P_{\text {poз }}, S_{k}\right)\right) .
$$

Practical calculations for the selected UAV types presented the following results:

$$
\begin{aligned}
& H_{1, \text { opt }}=H\left(Y_{1}=20,6\right)=1597 \mathcal{M}, \\
& H_{2, \text { opt }}=H\left(Y_{2}=29,4\right)=1318 M .
\end{aligned}
$$

Thus, the optimum values of UAV flight altitude $H_{o p t}$ were obtained, regarding required resolution $R_{0}$, recognition probability $P_{\text {роз, and }}$ frame area $S_{k}$. This enables the UAV operator to determine the optimum UAV flight altitude for a particular task, and (if several UAVs are available) to select one of them for the flight task, considering prior known information.

\section{CONCLUSIONS}

The article introduces a new approach to defining the UAVs optimal flight altitude when performing aerial photography tasks. In the course of the research the methods of combinatorial optimization and methods of solving multicriteria problems were used. In calculations, a multiplicative convolution of partial criteria was implemented. The flight altitude was determined by the required resolution to determine the assigned tasks, the probability of recognizing aerial photography objects and the frame area of imagery.

The prospect of further research is the program implementation of the method being introduced and further consideration of the specifics of the tasks. In addition, it is proposed to take into account meteorological and light conditions when performing the tasks. 


\section{REFERENCES}

1. Hlotov, V. (2014). Analiz mozhlyvostei zastosuvannia bezpilotnykh litalnykh aparativ dlia aeroznimalnykh protsesiv [Analysis of the possibilities of using unmanned aerial vehicles for aerial photography processes]. Suchasni dosiahnennia heodezychnoi nauky ta vyrobnytstva, 2, 6570 (in Ukrainian)

[Глотов, В. (2014). Аналіз можливостей застосування безпілотних літальних апаратів для аерознімальних процесів. Сучасні досягнення геодезичної науки та виробництва, 2, 65-70].

2. Walker, A. (2011). Hard Real-Time Motion Planning for Autonomous Vehicles (Doctoral thesis). Swinburne University.

3. Fryz, S. P., Myklukha, V. A., Maryshchuk, L. M., \& Avsiievych, R. O. (2019). Metod optymizatsii marshrutu bezpilotnoho litalnoho aparata $v$ khodi vykonannia zavdan na zadanii vysoti [The method of optimizing the route of an unmanned aerial vehicle during the execution of tasks at a given altitude]. Zbirnyk naukovykh prats ZhVI, 17, 133-142 (in Ukrainian) [Фриз, С. П., Миклуха, В. А., Марищук, Л. М., \& Авсієвич, Р. О. (2019). Метод оптимізації маршруту безпілотного літального апарата в ході виконання завдань на заданій висоті. Збірник наукових праць ЖВI, 17, 133-142].

4. Boloban, S. I., \& Horshenin, O. Ye. (2009). Deshyfruvannia aerokosmichnykh znimkiv [Deciphering aerospace images] (Vol. 1). Zhytomyr: ZhVI NAU (in Ukrainian) [Болобан, С. I., \& Горшенін, О. Є. (2009). Дешифрування аерокосмічних знімків (Частина 1). Житомир: ЖВІ НАУ].

5. Protsenko, M. M. (2012). Analiz metodiv tsyfrovoi obrobky videozobrazhen aparaturoiu bezpilotnoho litalnoho aparata. Visnyk ZhDTU, 3(62), 67-72 (in Ukrainian) [Проценко, М. М. (2012). Аналіз методів цифрової обробки відеозображень апаратурою безпілотного літального апарата. Вісник ЖДТУ, 3(62), 67-72].

6. Fryz, P. V. (2017). Udoskonalenyi matematychnyi aparat dlia vyznachennia sposterezhuvanoi ploshchi zadanoho raionu zemli u zavdanniakh kosmichnoho monitorynhu [Advanced mathematical apparatus for determining the observed area of a given area of the earth in space monitoring tasks]. Visnyk ZhDTU. Seriia: Tekhnichni nauky, 2(80), 126-134. doi: 10.26642/tn2017-2(80)-126-134 (in Ukrainian)

[Фриз, П. В. (2017). Удосконалений математичний апарат для визначення спостережуваної площі заданого району землі у завданнях космічного моніторингу. Вісник ЖДТУ. Серія: Технічні науки, 2(80), 126-134. doi: 10.26642/tn-2017-2(80)-126-134].

7. Voronin, A. M., Ziatdinov, Yu. K., \& Klymova, A. S. (2009). Informatsiini systemy pryiniattia rishen [Information systems for decision making]. Kyiv: NAU-Druk (in Ukrainian) [Воронін, А. М., Зіатдінов, Ю. К., \& Климова, А. С. (2009). Інформаційні системи прийняття рішень. Київ: НАУ-Друк].

8. Shmatok, S. O. (2010). Deiaki dzherela bahatokryteriinosti zadach doslidzhennia operatsii i rekomendatsii shchodo yikh rozv'iazannia [Some sources of multicriteria of operations research tasks and recommendations for their solution]. In Problemy stvorennia, vyprobuvannia, zastosuvannia ta ekspluatatsii skladnykh informatsiinykh system (pp. 86-95). Zhytomyr: ZhVI NAU (in Ukrainian)

[Шматок, C. О. (2010). Деякі джерела багатокритерійності задач дослідження операцій і рекомендації щодо їх розв'язання. В Проблеми створення, випробування, застосування та експлуатації складних інформаційних систем (с. 86-95). Житомир: ЖВІ НАУ].

9. Branke, J., Deb, K., Miettinen, K., \& Slowinski, R. (2008). Multiobjective Optimization: Interactive and Evolutionary Approaches (Lecture Notes in Computer Science). Springer.

10. Fryz, S. P., \& Petrozhalko, V. V. (2011). Analiz protsesu planuvannia kosmichnoho znimannia yak bahatokryterialnoi zadachi pryiniattia rishen [Analysis of the space survey planning process as a multicriteria decision-making task]. Systemy upravlinnia, navihatsii i zv'iazku, 3(19), 29-33 (in Ukrainian) 
[Фриз, С. П., \& Петрожалко, В. В. (2011). Аналіз процесу планування космічного знімання як багатокритеріальної задачі прийняття рішень. Системи управління, навігації і зв'язку, 3(19), 29-33].

11. Shmatok, S. O. (2011). Zghortannia vektornykh pokaznykiv efektyvnosti [Collapse of vector performance indicators]. In Problemy stvorennia, vyprobuvannia, zastosuvannia ta ekspluatatsii skladnykh informatsiinykh system (pp. 56-64). Zhytomyr: ZhVI NAU (in Ukrainian) [Шматок, С. О. (2011). Згортання векторних показників ефективності. В Проблеми створення, випробування, застосування та експлуатації складних інформаційних систем (с. 56-64). Житомир: ЖВІ НАУ].

12. Hrytsiuk, Yu. I., \& Hrytsiuk, M. Yu. (2014). Osoblyvosti multyplikatyvnoho zghortannia chastkovykh kryteriiv v uzahalnenyi pokaznyk [The Peculiarities of Multiplicative Coagulation a Partial Criteria Into One Generalized Index]. Naukovyi visnyk NLTU Ukrainy, 24(11), 341-352 (in Ukrainian)

[Грицюк, Ю. І., \& Грицюк, М. Ю. (2014). Особливості мультиплікативного згортання часткових критеріїв в узагальнений показник. Науковий вісник НЛТУ України, 24(11), 341352]. 